\title{
Technology Push vs. Market Pull in Technology University Innovation Commercialization Case Study: ITB
}

\author{
*Indriany Ameka, Wawan Dhewanto \\ School of Business and Management, Institut Teknologi Bandung, Indonesia \\ *indriany.ameka@sbm-itb.ac.id
}

\begin{abstract}
Technology-based innovation can comes either from market needs (market pull) then obtained the discovery of new innovation technology to help meet the needs of the community or from new invention which was later adapted by the community (technology push) that become useful new needs. The purpose of this paper is to determine the implications that what works better between technology push or market pull in technological innovation carried out by researchers in creating new technologies. In this paper, the study used the example of one of the universities in Indonesia, the ITB because it has a research institute that more active than any other university in Indonesia. Sample taken from the new product invention that have been successfully commercialized or not. To know whether successfully commercialized inventions are more likely depart from the market pull or technology push. We got the result of this research from technology innovation product that has been patented, from dept interviews by the researchers in ITB, and from focus group discussion among the junior researchers. The result of technology innovation product that only has been patented and the technology innovation product that already is commercialized and used by many people will be different. We will see the beginning of the idea appearance and the commercialization of their product innovation in the market from the researchers.
\end{abstract}

Keywords: Market Pull, Technology Push, University Patent, Technology Innovation and Commercialization

\section{Introduction}

Commercialization of university patents is becoming an important agenda, leading to new manifestations towards entrepreneurial university. The importance of commercialization of university patents can be seen through the contribution of university spin-offs towards local economic development (Etzkowitz, 2002; Etzkowitz, 2003; Shane, 2004). Universities keep patenting their invention even though the ratio of exploited patents is small compared to unexploited patents. According to Brem \& Voigt (2009) "technology push and market pull cannot be declared as the right or the wrong way to sustainable innovations. It depends on assorted variables-such as the specific industry, the company's history, etc.which strategy suits best. Some companies are still on the right track by focusing on technology or market needs only." This paper try to discuss the issue which theory between market pull and technology push in innovation are best to be implied in starting to make a technology innovation product in university as a guideline for every inventors when they start to think about inventing a new invention. The success of this product technology innovation is measured from the successful commercialization of the products that have been patented. The research question for this paper is which one better between market pull or technology push that affect the best successes commercialization for new product innovation that has been patented by the inventor from university?

\section{Literature Review}

Researcher's motivation and characteristics to discover idea and commercialization of product innovation: Every inventor can be an entrepreneur if their motivation is being push with the desire to make their invention exploited with commercialization and followed only with the desire of independence to create wealth (Blair and Hitchen, 1998; Shane \& Khurana, 2003; Shane, 2004). According to the research before, for those inventors whose patents were not exploited, some do possess entrepreneurial traits (Ismail, 2007, Ismail et al 2010). The other factors that influence are the inventors background, their motivation to commercialize, opportunity recognition and industrial experience, the stage of technologies, and the roles of TTO (Technology Transfer Office) that university has. However, because of the main purpose of those research (the research before from Ismail, 2007 and 2010) is to find the factors that influencing the inventors to commercialize the technology, we only use the theory to find and conclude the type of patent model they developed. The exploited patent divided into two type, the 
patent that commercialize to spin-off company and the patent that commercialize to establish company and the factors that involving the unexploited patent (Ismail et al 2011). In this paper, to see the pattern of the inventors about how to think the initial creation of a new product and what will they do to the results of their discovery? Everyone departs from a different mindset. Some people will see what is needed by the community first, and then try to find a product that can meet and satisfy the needs of that market. People who like this trying to make innovation based on market needs. Some others will be thinking with their high imagination about what you think will be required by the public/community, a product that can be useful for many people. While people who think in this way, their invention departs from technology push. Both have different characteristics in view of the market. So the research in this paper, which is more successful to be applied in the discovery of an innovation in the university.

Market Pull vs. Technology Push: Every innovation compulsions can come from two different ways (Boehme, 1986; Brockhoff, 1969; Bullinger, 1994; Schoen, 1967):

Market pull/market needs/demand pull/need pull: Innovation that come from this source begin with the dissatisfaction of customer needs of the product or service at the market, and create problem solving for this demand ('invent-to-order' a product or service for a certain need). The compulsions come from a person or groups who are willing to express the demand from the market become a concrete product or service that can be used for many people that needed.

Technology push: Innovation that come rom this source begin with the dissatisfaction of researcher (internal or external) with the same in growing old product or service, then the main purpose is to commercialize of new know-how product or service. The compulsion comes from the application push of competence in technology. This compulsion of technology push does not look to the market whether the demand is exist or not. Walsh et al. (2002) characterized technology push as a creative or destructive of a product or service in the market, while market pull as a replacement or substitute. The summary of deficiencies and shortcomings of technology push and market pull describe in table 1 below (Burgelman and Sayles, 2004).

Table 1: Summary of deficiencies and shortcomings of technology push and market pull

\begin{tabular}{ll}
\hline Technology push & Market pull \\
\hline $\begin{array}{l}\text { Risk of starting with what can be researched and } \\
\text { evaluated easily }\end{array}$ & $\begin{array}{l}\text { Risk of looking only at needs that are easily } \\
\text { identified but with minor potential }\end{array}$ \\
$\begin{array}{l}\text { Risk of addressing the needs of the atypical user } \\
\text { Continuing to change the definition of the } \\
\text { 'opportunity'; 'miss the opportunity' } \\
\begin{array}{l}\text { Potential for getting locked into one technical } \\
\text { solution }\end{array}\end{array}$ & Lack of being a 'champion' or 'true believer' \\
\hline
\end{tabular}

There is also another aspects that impact the new product or service innovation implementation, it is the entrepreneurial aspects of pro-activeness and risk taking (Salavou and Lioukas, 2003).Consequently, the successful of a new innovation product or service depend on the targeted arrangement of market pull and technology push (Hauschildt, 2004). With the purpose to accomplish this, networking capability is acknowledge as the essential key of success factor. According to Burgelman and Sayles (2004), there are three major elements to persistent the relationship between market pull and technology push for describe the possible of new business opportunities:

- Technology sources: "Research only works if the researcher's personal interests are being adequately considered, combined with existing corporate expertise, and supplemented with continuing the overview of new technological developments. 'Bootleg research' is a way of pursuing an idea against all organizational odds, but if there is no applicable workflow processing afterwards, this kind of research should be avoided."

- Market demand: This one conduct by the marketers on doing everlasting research in the market, especially in the area of customer disappointment of every products and services. Furthermore, estimating the possible of new need satisfaction for the future is very important. 
- Relevant Problem: This is the first compulsion either from internal or external sources to make a new innovation, such as ideas and trends.

Technology Commercialization: According to Drucker (1973) wrote on his book that "Because the purpose of any business is to create a customer, the business has two basic functions: innovation and marketing. Marketing and innovation produce result, all the rest are cost". This mean that commercialization happen in marketing area, how to commercialize to the customer to make sure they know and have the interest to buy the new product innovation introduce to the market.

\section{Methodology}

This paper is centered on a single case study in one of the university in Bandung. Two types of patents were selected: exploited and unexploited patents. We analyze the individual characteristic, motivations and ability to recognize opportunities from dept-interview survey. The survey will show us which kind of innovation product that successfully be commercialize after being patented, is it the patent that depart from market needs or from technology push by the inventor. The respondent taken from the person who is listed on the patent data from university institution. We conduct further interview to some of them and some other researchers that never patent through the institution, but already commercialize their new innovation through establish company or other different way.

Figure1: Flow of the commercialize patent

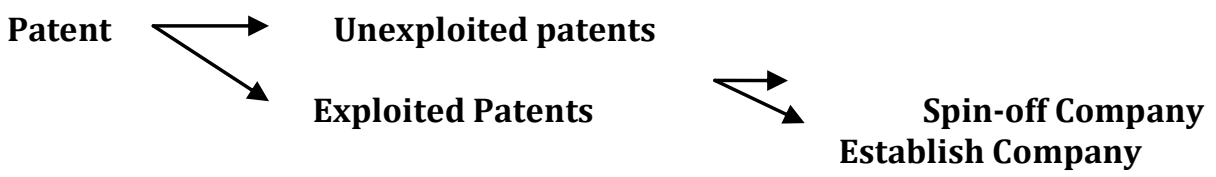

The figure above is a framework according to Ismail et al (2011), but in this paper, we will only examine until the stage of unexploited and exploited patent. Because we defined the unexploited patent as technology that cannot be commercialized and exploited patent as a technology that has been commercialized. We determine that an innovation that comes from the project of inventors in every university as a market demand. Project in here means, that the new idea to invent a new product innovation comes from other person or other company, the inventor only develop the needs to be a new innovation but the basic idea of what the market need not comes from his / her own observations. Even the innovation does not come from the ideas of each inventor himself, but the idea is developed with the knowledge that they had.

\section{Findings}

From the data that we obtained, there are 31 patents that are listed in the university. This list is derived from the institution inside the university where the researchers registered their patents. This institution accommodates all innovasion product that need to be patent. Therefore, the function of this institution is to help inventors obtain their patents. However, for commercialization, the institution has not been able to become solution for the inventor, because these institutions cannot help to commercialize the results of innovation to find a market that can be a goal for every product to be commercialized. Therefore, to find out how the continuity product innovation that has beeen patented, we do further interview directly to several inventors. From the 31 patents, we found that most of the patents are unexploited patent and almost all of the patents are depart from technology push. Result shown from the data we found, that the inventors who tried to patent their technology innovation product are the inventors that essentially depart their product from technology push. Because they cannot commercialize their product yet, the safest way is to patent their product first. Through this, we knew that new technology innovation product that was departed from technology push is hard to commercialize. The direct interview that we conduct to the inventors, help us a lot, we knew details how the technology innovation product depart, whether from the market pull or technology push and the detail of commercialization progress of the product.

The interviews conduct to some of the inventors that the product technology has been patented and the inventors that their innovation product has not been patented. The results from the interviews showed that most inventors in university always depart their product innovation based on projects they have got. The project can be from government or from independent company. They pay the university inventors to 
develop their basic idea of a new product they wanted. Once the product is completed and ready to be commercialized, a new emerging innovations show up in technology. Then the results of these innovations become the property of company or government agency. Therefore, the inventors are not really concerned about the patent of the product, since it is not they who need to commercialize that product. From the focus group discussion that we conduct with other junior researchers and inventors, they said that most of the inventors depart their new technology innovation is based on project bbecause it is hard to depart their product innovation from technology push. Because when they depart from the technology push, they have to think how to commercialize it to gain the achievement and wealth. But if they depart the new product from market pull, they will fulfill the market need in a short term because the community needs is always change rapidly. Meanwhile if they depart the new product from technology push and they successfully commercialize it the life cycle of that product will stay longer in community than the product comes from market pull. There are many factors inside and outside the university that give them trouble with the bureaucracy if they want to patent their new product. Besides, the university does not have a TTO (Technology Transfer Office) whose function is to commercialize every new product innovation that the inventors inside the university made. The university only help to patent the new product innovation without help in the matter of commercialize the new products. So basically, every inventor has to think their own market of their product to be commercialized.

\section{Conclusion}

Most of the patents that listed on depart from technology push as the findings of technology innovation. Almost all of the patents are also unexploited patent. In other words, we can conclude that new product innovation that was departed from technology push is hard to commercialize bbecause of many factors inside the university make them difficult to commercialize their innovation product. If an inventor cannot see the opportunities of the market then it would be better if they depart their technology innovation from market pull or from projects that offered to them by the government or independent company. Conversely, if an inventor wants to depart their technology innovation from technology push, they have to be smart in analyze the market first to know where they have to commercialize their product. Therefore, even they depart their technology innovation from technology push; they still have to understand the market needs. It is easier to them to depart their technology innovation product from market pull that has been analyze by other parties. Other parties in here mean the government agency or independent company. Another way if they still want to depart their technology innovation product from technology push, it is easier and really helps them if university has TTO to accomodate their technology push product, which will help them to find which market segment, will appreciate and accept their product.

Contribution and Implication: From this paper, every researcher that wants to make a new product or service innovation can decide where they begin their idea, to make their consideration more scientifically. It is helping them to derive their strategy next for commercialize their product or service innovation. Whether they only want to patent it, to gain wealth, or just hoping to make their new innovation wellknow to achieve the public interest.

Limitation of Study: This study has provided the significant understanding in decision-making process of strategy in making new technology innovation product. However, there is some limitation in this study. This research only conduct for single case study, we do not know the implication of market need and technology pushes in other universities, which impact the generalization of the conclusion. According to the patent holder in the institution at the university said that not all the new product innovation patent to them, it makes the data bias. Furthermore many inventors who have patented their product did not report back on how the commercialization of its products. Possible non-response bias also occurred because of many of inventors are refuse or too busy to be interviewed. That is why further research is open to be conducted to see the implementation in all places, to gain more reliable conclusion.

\section{Reference}

Blair, D. M. \& Hitchen, D. M. W. N. (1998). Campus Companies - UK and Ireland, Brookfield, USA: Ashgate Publication.

Boehme, J. (1986). Innovationsfo" rderung durch Kooperationen: Zwischenbetriebliche Zusammenarbeit als Instrument des Innovationsmanagements in kleinen und mittleren Unternehmen bei Einfu" hrung der Mikroelektronik in Produkte und Verfahren. Erich Schmidt Verlag, Berlin. 
Brockhoff, K. (1969). Probleme und Methoden technologischer Vorhersagen. Zeitschrift fu" $r$ Betriebswirtschaft, 39(2), 1-24.

Brem, A. \& Voigt, K. (2009). Integration of market pull and technology push in the corporate front end and innovation management-Insights from the German software industry. Technovation, 29, 351367

Bullinger, H. J. (1994). Einfu“ hrung in das Technologiemanagement. Modelle, Methoden, Praxisbeispiele. Teubner, Stuttgart.

Burgelman, R. A. \& Sayles, L. R. (2004). Transforming invention into innovation: the conceptualization stage. In: Christensen, C.M., Wheelwright, S.C. (Eds.), Strategic Management of Technology and Innovation. McGraw-Hill, Boston, 682-690.

Drucker, P. F. (1973). Management: Tasks, Responsibilities, Practices, HarperCollins, New York.

Etzkowitz, H. (2002). MIT and the Rise of Entrepreneurial Science, London: Routledge.

Etzkowitz, H. (2003). Research Groups as 'quasi-firms': the Invention of the Entrepreneurial University. Research Policy, 32(1), 109-121.

Hauschildt, J. (2004). Innovations management. Vahlen, Mu“ nchen.

Ismail, K. (2007). Commercialization of University Patents: A case study. PhD Thesis University of Stratchlyde.

Ismail, K., Cooper, S., Omar, W. Z. \& Majid, A. (2010). University Spin-off Formations: How decision making process has been made? Journal of Business and Social Science, 1(2).

Ismail, K., Omar, W. Z. \& Majid, A. (2011). Commercialization of University Patents: A Case Study. Journal of Marketing Development and Competitiveness, 5(5).

Salavou, H. \& Lioukas, S. (2003). Radical product innovations in SMEs: the dominance of entrepreneurial orientation. Creativity and Innovation Management, 12(2), 94-108.

Schoen, D. A. (1967). Technology and Change: the New Heraclitus. Delacorte Press, New York.

Shane, S. \& Khurana, R. (2003). Bringing Individuals Back in: The Effect of Career Experiences on New Firm Foundings. Industrial and Corporate Change, 12(3), 519-543.

Shane, S. (2004). Academic Entrepreneurship: University Spin-offs and Wealth Creation, Cheltenham: Edward Elgar.

Walsh, S. T., Kirchhoff, B. A. \& Newbert, S. (2002). Differentiating market strategies for disruptive technologies. IEEE Transactions on Engineering Management, 49(4), 341-351. 